\title{
Maintaining Positive Branding of Regional Heads Amid the Covid-19 Pandemic
}

\author{
Agus Machfud Fauzi ${ }^{1, *}$ \\ ${ }^{1}$ Department of Social Science, Faculty of Social Science and Law, Universitas Negeri Surabaya, Surabaya, Indonesia \\ *Corresponding author. Email: agusmfauzi@unesa.ac.id
}

\begin{abstract}
Regional heads are leaders who face the people directly at the regional government level in Indonesia, in contrast to the President who is geographically distant from the people. The covid-19 attack comes suddenly, there is no long preparation process, if the regional head is unable to handle the Covid-19 pandemic then he will have a negative image by the people. Regional head elections will be held at the end of 2020, if the regional head fails, it is likely that he will not be re-elected in the second term. For those who have been in two periods, they will get a red report card from their people, even though during these two periods they have had programs and policies to bring local government to the welfare of their people. This study aims to reveal the strategy of the regional head to maintain a positive image so that he gets the recognition of the people as a protector and savior of his people for the next life. This study uses the framing method by Erving Goffman to produce data that makes it easier to process and analyze. This research resulted in, first, for regional heads who want to move back to contestation to the second period, so they try their best to gain sympathy for the handling of covid1-9. The incumbent sees this virus disaster as a blessing, an exciting opportunity. Second, in the morning for regions that have been in two periods, they will maintain their positive branding so that the success of these two periods is not erased by the Covid-19 pandemic.
\end{abstract}

\section{Keywords: Kepala Daerah, Branding, Keberhasilan, Covid-19}

\section{INTRODUCTION}

The regions are still obliged to carry out their government in the atmosphere of the Covid 19 pandemic. This phenomenon is different from the previous one in that they were able to carry out all their work programs easily and smoothly. This is because there are no obstacles in running the government in a normal atmosphere. [1]

The presence of the COVID-19 pandemic in early 2020 has disrupted government implementation. Regional heads cannot optimally run their government because covid19 is developing rapidly without knowing class and caste in human life. They government officials have a fear of the same virus so caution is the nature of the government elite. [2]

The problem is that in 2020 there will be Pilkada implementation in 270 regions throughout Indonesia. Pilkada is used to elect Regional Heads and Deputy Regional Heads. Both those who are in the province, regency and municipality, whose terms of office for the pair of regional heads and deputy regional heads have ended.

In the current regulation, that regional heads who have served two terms as regional heads, as well as their representatives, are not allowed to come forward as candidates. This happens because regulations are made to limit a person's leadership so that they do not enter the realm of "the power tend to corrupt". [3]

There is a different phenomenon in the figure of the incumbent regional head, between those who will come back as a candidate for head, because there is still a chance to go forward again, compared to the head of the incumbent region who has no chance of returning to contest. The difference is very striking in several areas, between serious community service work, especially handling the Covid 19 pandemic and community service programs in general. [4]

Incumbents who are no longer progressing in Pilkada contestation, they tend to work optimally without any distortion of the program from the central government or the provincial government. They have a desire to complete their work program by producing the best for the region 
and its people. What they are looking for is appreciation from the community, so that no one gets injustice and misery in social life amidst Covid 19 sufferers.

The incumbent who returns as a candidate for regional head, has a different way of dealing with the atmosphere of the Covid 19 pandemic. He will take advantage of the opportunity to present himself as a hero. This image is a creative and energetic candidate for the head of the incumbent region. They like the challenge of turning something negative into a positive state. They do not think that various disasters are something that must be found a way out for the sake of their people. This phenomenon makes the incumbent different, because some are sincere in implementing it for their people, some have other objectives in implementing this good program.

These two phenomena are discussed in this article, so as to get solutions related to people's problems. The positive branding of regional heads is a discussion that departs from assumptions, then research is carried out.

\section{METHOD}

In a study that raised the positive branding of regional heads in the midst of the COVID-19 pandemic, I used a qualitative research method [5] using the framing method [6] by Erving Goffman to produce data that made it easier to process and analyze the branding of regional head candidates.

Researchers collected data from several media that reported on the efforts and creations of regional heads in handling Covid 19 in the Ponorogo and Surabaya areas. The choice of these two places is because: First, Tri Rismaharini is a regional head (mayor) who has served as leadership for two terms, so he is not allowed to run again as a candidate for mayor of Surabaya for the 2020-2025 period. Second, Ipong Muchlisoni is a regional head in Ponorogo Regency who has only served one term so that he has the opportunity to run again as a candidate for regional head for the 2020-2015 period. Third, the two regional heads have sufficient coverage in the media, making it easier for researchers to obtain data and analyze it.

The questions asked are: 1. How is the positive branding as a regional head for handling covid 19 in the two regional governments (Tri Rismaharini in Surabaya City, and Ipong Muhlisoni in Ponorogo Regency)? 2. How is public acceptance of the branding of the two regional heads?

\section{RESULTS AND DISCUSSION}

The Mayor of Surabaya, Tri Rismaharini, performed prostration in front of the doctors during an IDI audition with the Mayor of Surabaya. The mayor made prostration twice in front of the doctor because the hospital explanation was full. Rizma did not accept it when she felt blamed by dr. Sudarsono, who gave an explanation during the audition. [7]

Tri Rismaharini does not want a fuss in terms of handling the body of Covid 19. The solution to give up on families affected by Covid 19 is the Mayor's request for family members and neighbors not to have contracted Covid 19. The Surabaya city government has prepared a special covid 19 funeral in Keputih, Sukolilo and Acne Bladder. The sentence expressed was: "Because I don't want anyone to be affected by Covid-19. However, what can I do, because God has predestined and we must be able to accept this, so I beg you to let our brothers and sisters go". [8]

The Mayor of Surabaya enthusiastically came to residents to be informed about the regulations on the use of masks during the Covid 19 pandemic. He often visited residents in markets, village streets and strategic places, they were informed about the use of masks. If someone does not wear a mask because they do not have it, the mayor will give him a mask to use immediately. [9]

In contrast to Ipong Muhlisoni, the Regent of Ponorogo, who often conflicts with the community. This is because Ipong does not carry out activities like Tri Rismaharini. Regent Ipong, whose activities are only announcing news about community members affected by Covid 19.

The Regent of Ipong conveyed the news that the Ponorogo area affected by Covid had increased to 303. His announcement that Ponorogo seemed to continue to increase patients affected by Covid 19, some of whom died. But Ipong does not do anything practical for its citizens. [10]

There are 15 additional cases affected by Covid 19, namely those who have just returned from Surabaya and Jakarta. Seduah announces that those who are affected by Covid, then the community will implement health protocols, even though they themselves still often carry out activities that are counterproductive to those stated, for example often gathering time for dawn in congregation with a lot of participants. [11]

Ipong had a conflict with Ponorogo residents about the fate of 9 DPRD members who were declared by the Hospital to be declared Covid 19, but instead sought a 
comparison for another hospital, which then the Regent of Ipong announced that he was not negative from Covid 19. The conflict was very busy because he made a relative breakthrough. no one had repeated covid 19 tests with a different hospital. [12]

The picture of the two regional heads is different in responding to Covid 19. You can analyze the details one by one from the various reports, so that there is no misunderstanding in the objectivity of the analysis.

Tri Rismaharini thinks totally for the people, even though sometimes it is dramatic like prostration in front of the IDI doctor. The drama remains positive with the explanation that in the short term Rizma will not come forward as a candidate for regional head in the 2020 Pilkada. Her female character is out, her emotions are as much as possible so that she seems to have negative drama..

Ipong does not have creative ideas in responding to society. When there was Covid 19, he was limited to announcing the additions and subtractions. Actually, this can be done by his staff or medical personnel who are more professional in talking about the Covid 19 pandemic. Behind this, Ipong is seen as wanting to appear in front of the public that he as the incumbent has the responsibility to read it out.

Tri Rismaharini did not defend against the bureaucracy when exposed to Covid 19. Rizma served them enough to be facilitated by the medical team so that they could be served by professionals.

Ipong covered up the legislators who were affected by Covid 19, by finding the results of another examination from another hospital. In real terms, the public does not know whether an examination was carried out from another hospital, but a letter has been issued explaining that 9 DPRD members are negative from Covid 19. Those affected by Covid 19 are part of the winning team, so the public immediately gives a negative assessment of the letter explaining that they are negative from Covid 19. This is history, in contrast to other areas, that is, when a health worker labels a person with Covid 19, anyone will receive the letter, so that someone is immediately quarantined by the hospital, or at least self-quarantine.

The activities carried out by Mayor Tri Rismaharini in Surabaya and Regent Ipong Muhlisoni in Ponorogo are branding activities for him as a regional head. Branding is an effort for regions to present themselves the best in front of their people.

Positive branding is the main goal of regional heads when appearing in front of their people. The public has different perspectives on regional heads who do not want to go forward again and give way to the 2020 Pilkada, compared to running again as a candidate.

Positive perceptions will still be accepted by regional heads who do not progress again, even though the concerned person is too excessive in branding. As Tri Rismaharini did to prostrate before the doctor was too much, but because he did not go back to the contest in the Surabaya Regional Head Election, the public understood the mayor's image.

In contrast to Ipong Muhlisoni, who did branding by wanting to be at the forefront of handling Covid 19 in Ponorogo. Because the person concerned did not do creativity, what appeared in public, the Regent only wanted to be the frontman in handling Covid 19. If he was able to create creativity, there would be no negative assessment.

The good intentions of the two regional heads are basically the same, but on their way they become different, because they are faced with different realities of life. They should be able to cover up matters related to the contest preparation process for the 2020 Pilkada so that they don't get a negative assessment from the public.

Public acceptance is different for the two regional heads. First, the public is represented by the media, so the media do not think negatively about Tri Rismaharini so that whatever is conveyed and done is exposed smoothly, without any negative thoughts from the media crew, even though the mayor has excessive branding, for example to prostrate himself in an improper manner.

Second, the people of Surabaya are divided in several perspectives, there are those who think positively about what the mayor has done because it looks serious on media broadcasts. Some think negatively, namely Risma exaggerating in her branding. However, negative perceptions did not lead to a more negative condition towards Tri Rismaharini, they then understood the branding.

The media and society's assessment of what Ipong Muhlisoni did was different. The media presented news that was not positive for the Regent of Ipong, limited to reading the number of additions and subtractions affected by Covid 19. There was no creativity in the news, except only an appeal for the implementation of health protocols, for example washing hands, using sanitizers, wearing masks and so on.

Some Ponorogo people have a negative assessment of the Ipong Regent, because there is no creativity in handling Covid 19. What emerged on a large scale was the New Normal implementation campaign. In addition to the implementation of the dawn prayer in congregation in a 
structural and massive manner, because it involves the bureaucratic elite to pray at dawn congregations in various places on a safari to village mosques. This phenomenon is contrary to the spirit of stopping the handling of Covid 19 in Ponorogo Regency.

\section{CONCLUSION}

There are differences in the way regional heads respond to the covid phenomenon 19. Regional heads who will not go forward again in the 2020 Pilkada contest will not do anything wrong. If the person concerned has drama, it is limited to imaging as a regional leader who should carry out the dramaturgy. Whereas for incumbent areas that progress again have a tendency to make maximum use of the handling of Covid 19, if the person concerned is not creative then the implementation of handling only prioritizes branding, which sometimes has a counter-productive impact when the incumbent returns as a candidate for regional head.

\section{REFERENCES}

[1] M. Farisi, "Pemilihan Kepala Daerah sebagai Instrumen Sirkulasi Elit Politik Lokal: Studi di Provinsi Jambi Tahun 2015," Polit. J. Magister Ilmu Polit. Univ, 2016, [Online]. Available: http://journal.unhas.ac.id/index.php/politics/article/vie $\mathrm{w} / 3027$.

[2] M. Braiman, "Latitude Dependence of the COVID-19 Mortality Rate-A Possible Relationship to Vitamin D Deficiency?," Available SSRN 3561958, 2020, [Online]. Available: https://papers.ssrn.com/sol3/papers.cfm?abstract_id=3 561958 .

[3] Z. Maliki, Sosiologi politik: makna kekuasaan dan transformasi politik. books.google.com, 2018.

[4] A. M. Fauzi, FAKTOR-FAKTOR KEMENANGAN DAN KEKALAHAN PETAHANA Studi Tentang Pilkada Empat Provinsi di Indonesia 2012-2013. repository.unair.ac.id, 2018.

[5] M. D. White and E. E. Marsh, "Content analysis: A flexible methodology," Libr. Trends, 2006, [Online].
Available:

https://muse.jhu.edu/article/202361/summary.

[6] P. Nulty, Y. Theocharis, S. A. Popa, O. Parnet, and K. Benoit, "Social media and political communication in the 2014 elections to the European Parliament," Elect. Stud., 2016, doi: 10.1016/j.electstud.2016.04.014.

[7] Handoyo, "Ketika Tri Rismaharini sampai sujud di hadapan dokter terkait penanganan Covid-19," Kompas Jawa Timur, Surabaya, 2020.

[8] T. Mahadi, "Risma: Saya tak ingin ada keributan lagi soal jenazah pasien Covid-19," Kompas Jawa Timur, Surabaya.

[9] D. N, "VIDEO: Cara Wali Kota Risma Cegah Penularan COVID-19 di Surabaya," Liputan6.com, Surabaya, 2020.

[10] S. A. C. Sakti, "UPDATE Covid-19 di Ponorogo hingga 10 September 2020: Jumlah Kasus Terus Bertambah Artikel ini telah tayang di surya.co.id dengan judul UPDATE Covid-19 di Ponorogo hingga 10 September 2020 : Jumlah Kasus Terus Bertambah, https://surabaya.tribunnews.com/2," Surya.id, Surabaya, 10-Sep-2020.

[11] S. A. C. Sakti, "Ada 15 Kasus Covid-19 Baru di Kabupaten Ponorogo, Riwayat Pulang dari Surabaya dan Jakarta Artikel ini telah tayang di surya.co.id dengan judul Ada 15 Kasus Covid-19 Baru di Kabupaten Ponorogo, Riwayat Pulang dari Surabaya dan Jakarta, https://surabaya.tr," Ponorogo, 03-Sep2020 .

[12] E. H. Panca, "Bupati Ipong Pastikan Tak Ada Lagi Tambahan Kasus Covid-19 di DPRD Ponorogo Artikel ini telah tayang di surya.co.id dengan judul Bupati Ipong Pastikan Tak Ada Lagi Tambahan Kasus Covid-19 di DPRD Ponorogo, https://surabaya.tribunnews.com/2020/09/11/bupati," Surya.id, no. September, 2020, [Online]. Available: https://surabaya.tribunnews.com/2020/09/11/bupatiipong-pastikan-tak-ada-lagi-tambahan-kasus-covid19-di-dprd-ponorogo. 